\title{
The Relationship between Military Expenditures and Economic Growth: Panel Data Analysis for G-20 Countries
}

\author{
Assoc. Prof. Dr. Kutluk Kağan Sümer (Istanbul University, Turkey)
}

\begin{abstract}
As though it is a frequently researched topic that the relationship between military expenditures and economic growth, it is ignored that the level of military expenditures of countries based on their rival and allied countries or international organizations which they are members. Accordingly, in study, the relationship between military expenditures and economic growth is examined with the panel data analysis for 19 G-20countries. In this study two groups of Panel data models are applied. First panel group is military exporter. Second is military importer. The results of study support that feedback hypothesis exists for the U.S., growth hypothesis is valid for G-20 Countries and Turkey.

First hypothesis has been called as "growth hypothesis" based on the hypothesis of "guns or butter" depending on the study made by Benoit $(1973,1978)$ and finding of this study which is regarded as a pioneer for studies examining the relation between military expenses and economic growth. According to this hypothesis, there is a one-way positive causal relation from military expenses to economic growth. Second hypothesis is a hypothesis based on the argument of "guns or butter" and defending the view that there is a one-way causal relation from military expenses to economic growth but it is a negative one and called as "growth detriment hypothesis". Third hypothesis is a hypothesis based on the view that a two-way causal relation is effective in between military expenses and economic growth and called as "feedback hypothesis". According to this hypothesis, while military expenses have an effect on economic growth; economically more (less) developed countries allocate more (less) resource for military expenses (Kollias vd., 2004:557). And the last hypothesis is a hypothesis called as "neutrality hypothesis" and defending the view that there is no causal relation between military expenses and economic growth. According to this hypothesis, both military expenses does not affect economic activities, and economic growth is not effective on determination the level of military expenses.
\end{abstract}

\section{a. Economic Growth}

The concept of economic growth is nothing more than an increase of total production in agriculture, industry and services sectors of a country. It collects the basic factors which determine the national production in three groups as of modern development and growth theories, available production factors and growth rates, education and research activities and technologic changes. These basic factors and context of these factors are summarized in a table below (Table-1).

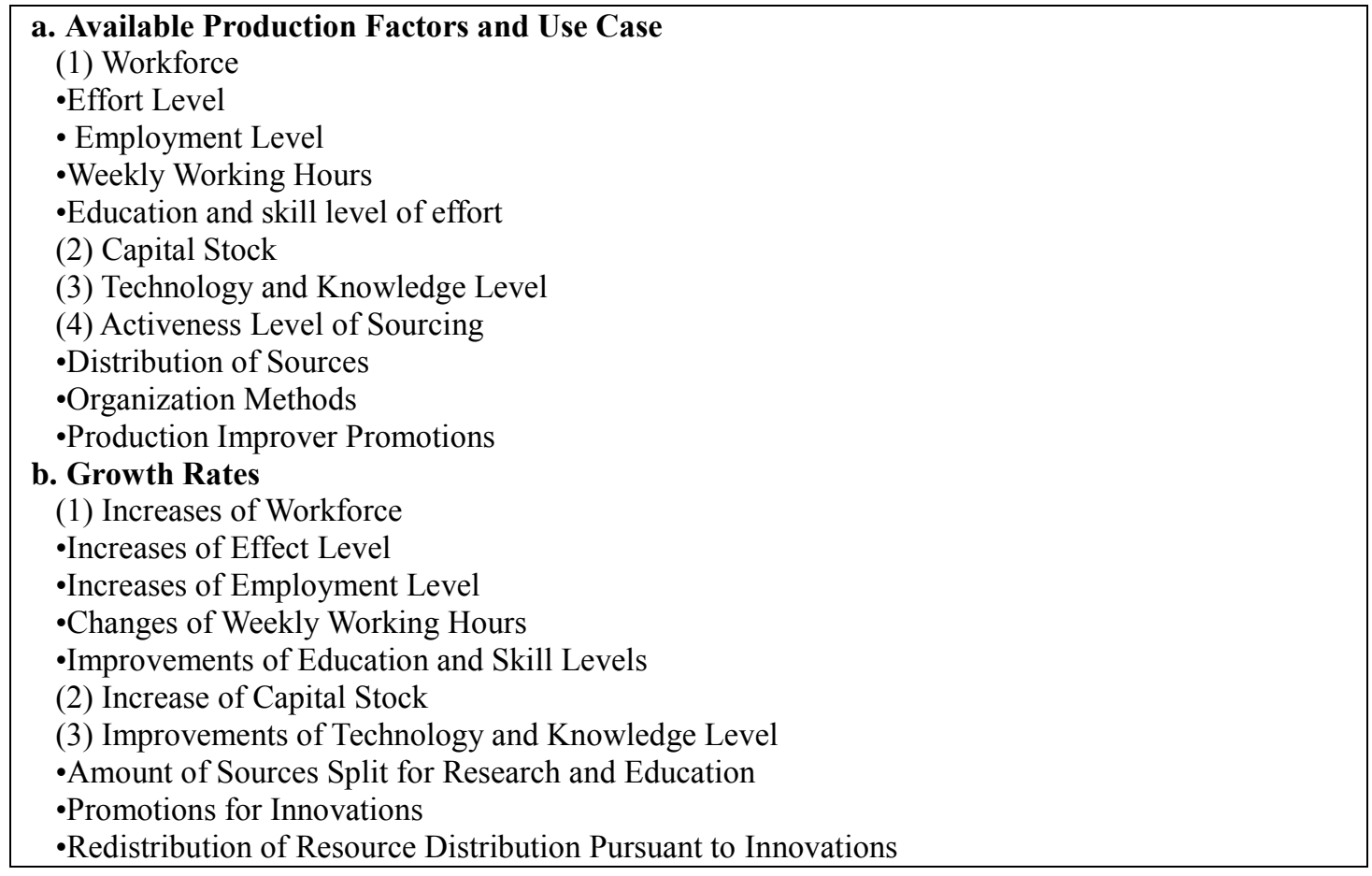

Table-1: Basic Factors Which Determine the National Production

\section{b. Defense Expenses}


Determination of military production, in a more concrete expression, determination of defense budget is based on two complementary different approaches. One of these approaches is foreign policy approach. In these approach, firstly worldview (in a more technical phrase, national values) then foreign policy of nation is determined. Later, the strategy which is necessary for effectuation of this foreign policy and appropriate military power for this strategy are planned. The expense to be required for this military power determines the defense budget. Second approach is called as domestic policy approach. In this approach, national development objectives and allocatable resource for these objectives are determined. When maximum limit of defense budget occurs in this resource distribution, developable military power alternatives in this limit is determined and then the most appropriate one of these alternatives for national defense objectives is selected. As we stated above, indeed it needs to address these two approaches as two complementary approaches. Following figure (Figure-1) shows that domestic and foreign policy approaches establish the whole national values together. In this figure, foreign approach is showed in left part under the title of foreign policy objectives; domestic policy approaches are showed in right part under the title of domestic policy objectives. It is impossible that a nation determines defense budget without considering developments of world policy and how these developments affect itself. Likewise, it cannot be rational to determine foreign policy objectives without considering national economic power.

\section{International and National Condition \\ Organizations and Decision Units}

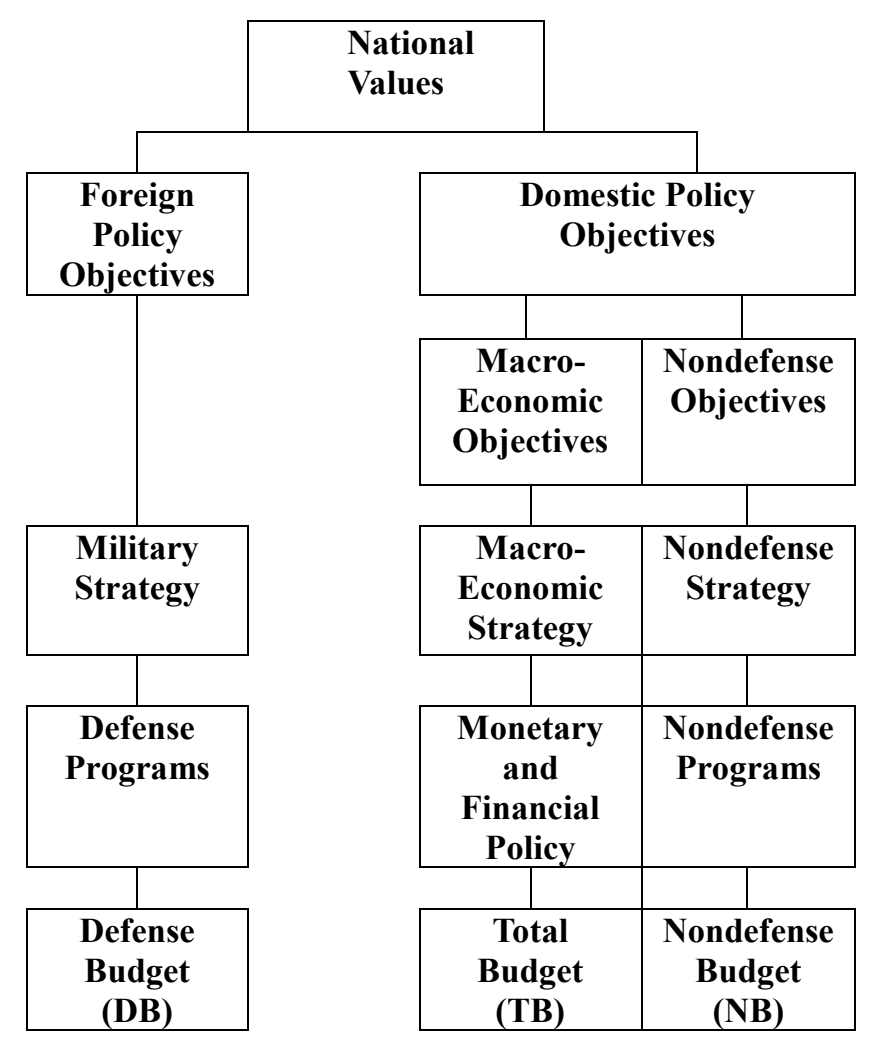

Figure-1: Evaluation Together of Domestic and Foreign Policy Approaches Source: War Economy; War Colleges Publications; Istanbul; 1985

\section{c. Defense Expenses and Economic Growth Relations}

Well, how can be defined the relation between defense expenses and economic growth? In shortly, it is possible to define this relation as increase on government expenses causes an increase on total demand in market; upliftment of industry by the mentioned demand increase and enlargement of economy with increasing industry production. However, expense of the mentioned growth (production growth) leads to increase of inflation. Even if demand shock creates short-term production growths at first, it does not change production level in long-term. It causes an increase on interest rates and inflation levels. Of course, this definition is an effective concept for government and defense expenses in state of a sudden shock wave.

In fact, general balance of economy will absorb the mentioned shock effect so as not to encounter an economic shock in long-term expenses.

If the American economy is examined, a lot of medium and large sized enterprises draw attention which make research for defense industry and produce defense industry systems. These enterprises play an important role in American economy in terms of whether new technologies they produced, or inputs they took from other sectors 
and outputs they gave the other sectors. If inputs they took from other sectors and outputs they gave the other sectors are examined, for example, defense industry takes a big support from scientific research sector and it financially supports this sector. Likewise, it supports sectors such as communication and transportation with its newly produced technologies. Today, communication technologies such as cell phone we used and aviation technologies are in state of output for defense industry. These output technologies positively affect the good and service production by making easier or faster transportation and communication. It is possible to evaluate this as a production shock.

Production-oriented shock (demand) in market both increases national income and decreases prices general level. This type of demand shocks generally appears thanks to new technologies. Industry revolution is one of the best examples for this type of demand shocks. It will decrease total demand in terms of economic policy, and promotions will be more effective than monetary and financial policies in terms of whether decrease price level or increase production.

On the other hand, according to two well-known economists of traditional economy, David RICARDO and Adam SIMITH; military expenses are nonproductive, confined to its own sector, only consuming and unnecessary expenses. They do not have effect on growth. According to 1973 economic growth report of the United Nations, defense expenses are shown as an important obstacle to growth for economies of developing countries.

On the other side, by giving arm markets of USA and Soviets in a bipolar world as examples, Paul Kennedy (1987) mentioned that the party which increases its military expenses, it will lose an important market by losing its share in world arms trade. According to Kennedy, arms trade is an economic activity which has an effect on production after all.

Meanwhile, it is necessary the people to defense themselves against their enemies to survive and defense expenses made for this.

Panel Data Analysis

Different types of data are used in economic studies. These types of data can only be analyzed with the models that are appropriate for their structure. Different analysis can be performed with time series data and horizontal vertical section data. The method of estimation of economic relations by using the section series that have time dimension is referred as panel data analysis. In this analysis, data set, which both have time dimension and section dimension, is formed by combining time series and section series. Today in many studies, data sets are formed by combining time and horizontal section data. Panel data model can be expressed as the equation below.

$$
\begin{aligned}
& Y_{\text {it }}=\beta_{1 i t}+\beta_{2 i t} X_{2 i t}+\ldots \ldots .+\beta_{\text {kit }} X_{\text {kit }}+e_{\text {it }} \\
& i=1, \ldots \ldots ., N \quad t=1, \ldots . ., T
\end{aligned}
$$

Here $\mathrm{N}$ defines units as $\mathrm{t}$ defines time. When $\mathrm{Y}$ variable became a dependent variable which has different values from one unit to another unit and from a time period to a consecutive time period, it can be expressed with two sub index which are $\mathrm{i}$ for section dimension and $\mathrm{t}$ for time period. This general model allows fixed parameters and regression parameters to separate each individual in each time period.

Panel data has various advantages when compared to horizontal section only or time series only. The advantages of using panel data are as follows: In panel data models, the number of observations will be more when compared to section and time series. In this case, the parameter estimations will be more reliable and the estimated models will depend on less restrictive assumption. Whereas, there is a risk of deviant results in studies with time series or section series only, the difference of the units cannot be controlled in detail. Moreover, panel data models allow establishment and control of behavior models more complex than section or time series. However, the omitted variables lead to deviation in estimating the results in studies. In case the omitted variable or the variables are stable with units or time, panel data usage provides the control of deviation. Another advantage of panel data usage is that, while only differences in between the units can be analyzed in making estimations using horizontal section data, by using panel data both differences in units and the difference in units by time can be analyzed (Baltagi, 1995; 3-5, Hsiao, 1986; 2-3).

In the model expressed in Equation (1), the coefficients take different values for different units in different time periods. In this case, the estimated number of parameters exceed the number of observations used i.e. model cannot be determined. Because of this disadvantage, in studies made with panel data different models can be obtained by making different assumptions about the characteristics of error terms and volatility of coefficients. Models obtained by different assumptions are "Fixed Effects" and "Random Effects" models. In each model, it is assumed that in all time periods and for all individuals, $\mathrm{e}_{i t}$ errors are distributed independently and as $\mathrm{N}\left(0, \sigma e^{2}\right)$ (Griffits, 1993; 571-573).

\section{a) Fixed Effect Models}

In studies utilized by panel data, a way to include the change caused by the difference in between the units or the change caused in between the units in time into the model is to assume that the current change will lead to a change in some or all of the coefficients of the regression model. Models which are assumed that the coefficients change by units or by units and time, are referred as "Fixed effect model" 
The general formulation of the model assumes that the difference in between the units can be captured in the differences in the fixed term (Pazarlıoğlu, 2001). For this purpose, panel data model can be assumed with the help of the dummy variable. When model number 1 is considered;

$$
\beta 1 \text { it }=\beta 1 ; \beta 2 \text { it }=\beta 2 ; \beta 3 \text { it }=\beta 3 \quad \text { (2) }
$$

is assumed. Here only the fixed parameters do change and the fixed term differentiate not by time but in section basis. So, even though the time dimension is reserved by the constant, it demonstrates difference in behaviors among individuals. Model number 1 becomes;

$$
\mathrm{Y}_{\mathrm{it}}=\beta_{1 \mathrm{i}}+\beta_{2 \mathrm{i}} \mathrm{X}_{2 \mathrm{it}}+\ldots \ldots . .+\beta_{\mathrm{ki}} \mathrm{X}_{\mathrm{kit}}+\mathrm{e}_{\mathrm{it}}
$$

If this model is rewritten by expanding the $\beta_{1 \text { it }}$ expression;

$$
\begin{aligned}
& Y_{i t}=\beta_{11} D_{1 i}+\beta_{12} D_{2 i}+\ldots \ldots . .+\beta_{1 N} D_{N i}+\beta_{2 i} X_{2 i t}+\beta_{k i} X_{k i t}+e_{i t} \\
& \sum^{N} \beta_{1 j} D_{j i}+\sum^{K} \beta_{k} X_{k t}+e_{i t}
\end{aligned}
$$

Here there are $\mathrm{N}$ number of units and $\mathrm{K}-1$ number of explanatory variables. Besides;

$$
D_{1 i}=\left\{\begin{array}{lc}
1, & i-1 \\
0, & \text { Other Cases }
\end{array} \quad, D_{1 N}= \begin{cases}1, & i-N \\
0, & \text { Other Cases }\end{cases}\right.
$$

In this model, as there is no fixed coefficient, the difference in between the $\mathrm{N}$ number of units is analyzed by using N number of dummy variables.

\section{b) Random Effect Models}

Studies utilizing panel data models, the change caused by units or the differences occurred according to units and time can be analyzed by using "Fixed Effect Methods" as well as "Random Effect Methods". In random effect model, the changes occurred in units or according to units and time are included in the model as a component of the error term. The main reason is to prevent the loss of degree of freedom encountered in fixed effect models.(Baltagi, 1995; 13). Because the important thing in random effects model is not having special coefficients for units or units and time but to have special error components for units or units and time. Moreover, in random effects model the section in the observed sample not only consider the effect of the differences occurred in units and time but also the effects other than the sample (Greene, 2003). We can explain the random effects model as follows. In model number (3), $\beta_{1 \mathrm{i}}$ can be taken as random variable;

$$
\beta_{1 i}=\bar{\beta}_{1}+\mu_{\mathrm{i}}
$$

and modeled like this. $\bar{\beta}_{1}$ i is universe mean constant and an unknown parameter. $\mu_{\mathrm{i}}$ are unobserved random errors that consider individual differences in individual behaviors. $\mu_{\mathrm{i}}$ are independent from each other from $\mathrm{e}_{\mathrm{it}}$. If the equation number (5) is placed in model number (3);

$$
\begin{aligned}
& \mathrm{Y}_{\mathrm{it}}=\left(\bar{\beta}_{1}+\mu_{\mathrm{i}}\right)+\beta_{2} \mathrm{X}_{2 \mathrm{it}}+\ldots . .+\beta_{\mathrm{k}} \mathrm{X}_{\mathrm{kit}}+\mathrm{e}_{\mathrm{it}} \\
& =\bar{\beta}_{1}+\sum_{k=2}^{K} \beta_{k} X_{k i t}+\left(e_{i t}+\mu_{i}\right)
\end{aligned}
$$

is obtained. The expression in $(6 b)$ is the general format of error component model. "Error component" expression is based on $\mathrm{e}_{\mathrm{it}}+\mu_{\mathrm{i}}$. This term is composed of two components: while $\mathrm{e}_{\mathrm{it}}$ indicates all errors, $\mu_{\mathrm{i}}$ indicates the individual "specific" error, individual differences and the change in between the individuals according to constant time.

\section{c) Hausman Test}

The coefficients that represent the unit or unit and time differences which is the validity of the hypothesis of error term components of random effects model being irrelevant from the independent variables in the model, can be analyzed by the test statistics suggested by Hausman (Greene, 2003). In this case, the difference between the fixed effect model parameter estimators and the random effects model parameter estimators should be analyzed whether for being statistically significant or not. In order to make a preference in between the two models Hausman test statistics is used. Hausman test statistics indicate the "Random effects estimator is right" and in zero hypothesis the chi-squared distribution of $\mathrm{k}$ degrees of freedom. In case of actualization, it can be decided that error terms components of random effects model are not relevant with independent variables. In this case fixed effects model shall be preferred.

\section{Used Data Set}

In this study, SIPRI Military Expenditure Database (C) SIPRI 2014 and IMF data have been used. Defense expenses belong to G-20 countries have been supplied from SIPRI and GSMH data from IMF database. It is studied with 22-year observation in between the years of 1992-2013. Used data logarithmic states of whether defense expenses or GSMH data. Thus, direct flexibilities between could be obtained.

\section{Empirical Results:}


After modelling studies had been made and Hausman test, it is decided upon Random effects model; after tests related to specification and deviations from assumptions were made on established random effects models, robust estimation models were established. During this modelling process, three different panel data econometrics model as of a model including all of the G-20 countries, a model including arms-exporting countries and a model including arms-importing countries were established. Finally, a classical economics model specific to Turkey were established. Main purpose here became the parameter tests according to country groups. Last-established classical economics model specific to Turkey, was accepted after tests had been made related to specifications and deviations from assumptions.

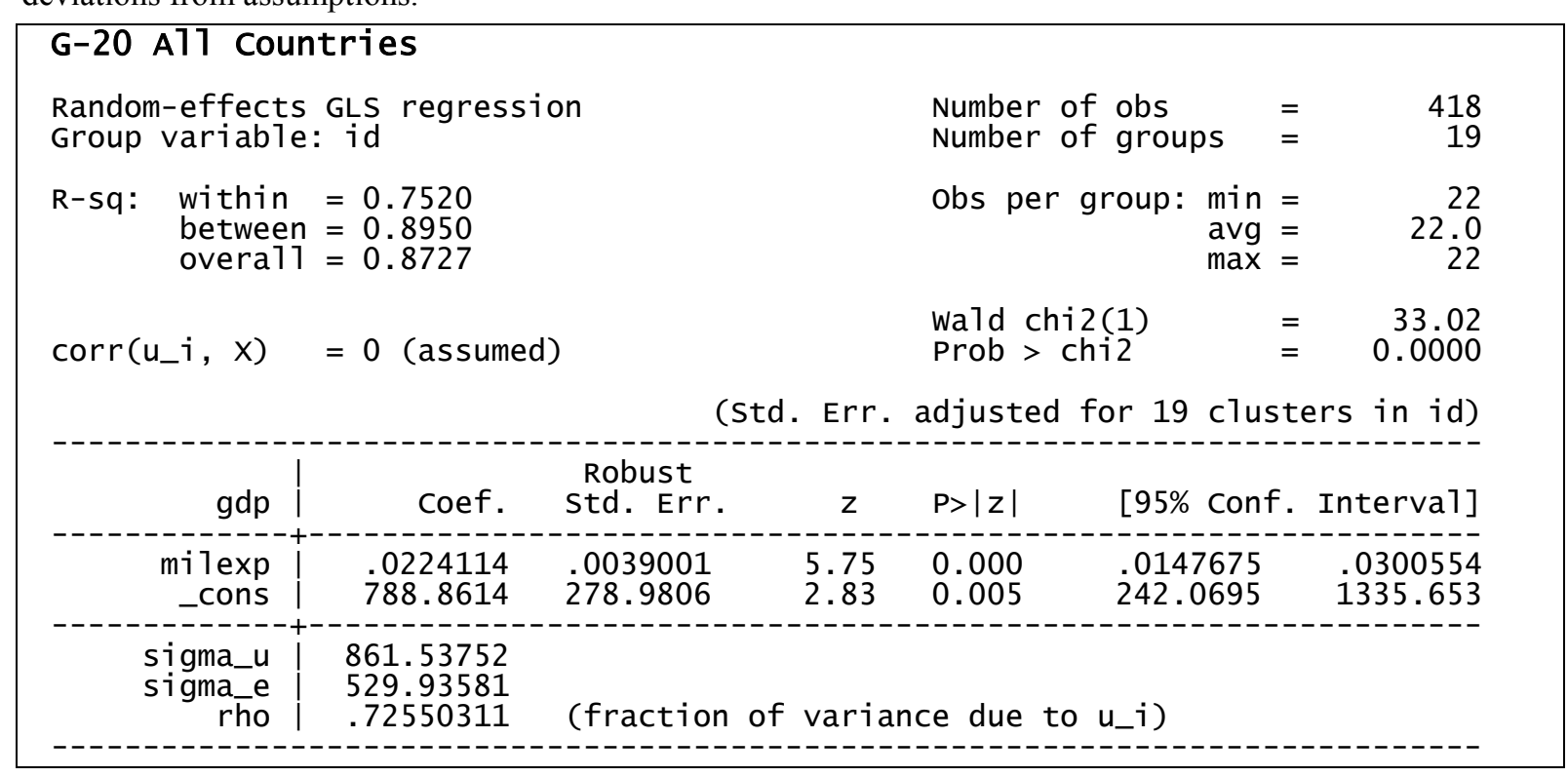

Table-2: G-20 All Countries Panel Econometrical Model Output

It is seen that defense expenses have a positive effect on general of G-20, when the model is examined. It has power to create $1 \%$ increase on military expenses and $0,022 \%$ increase on GSMH.

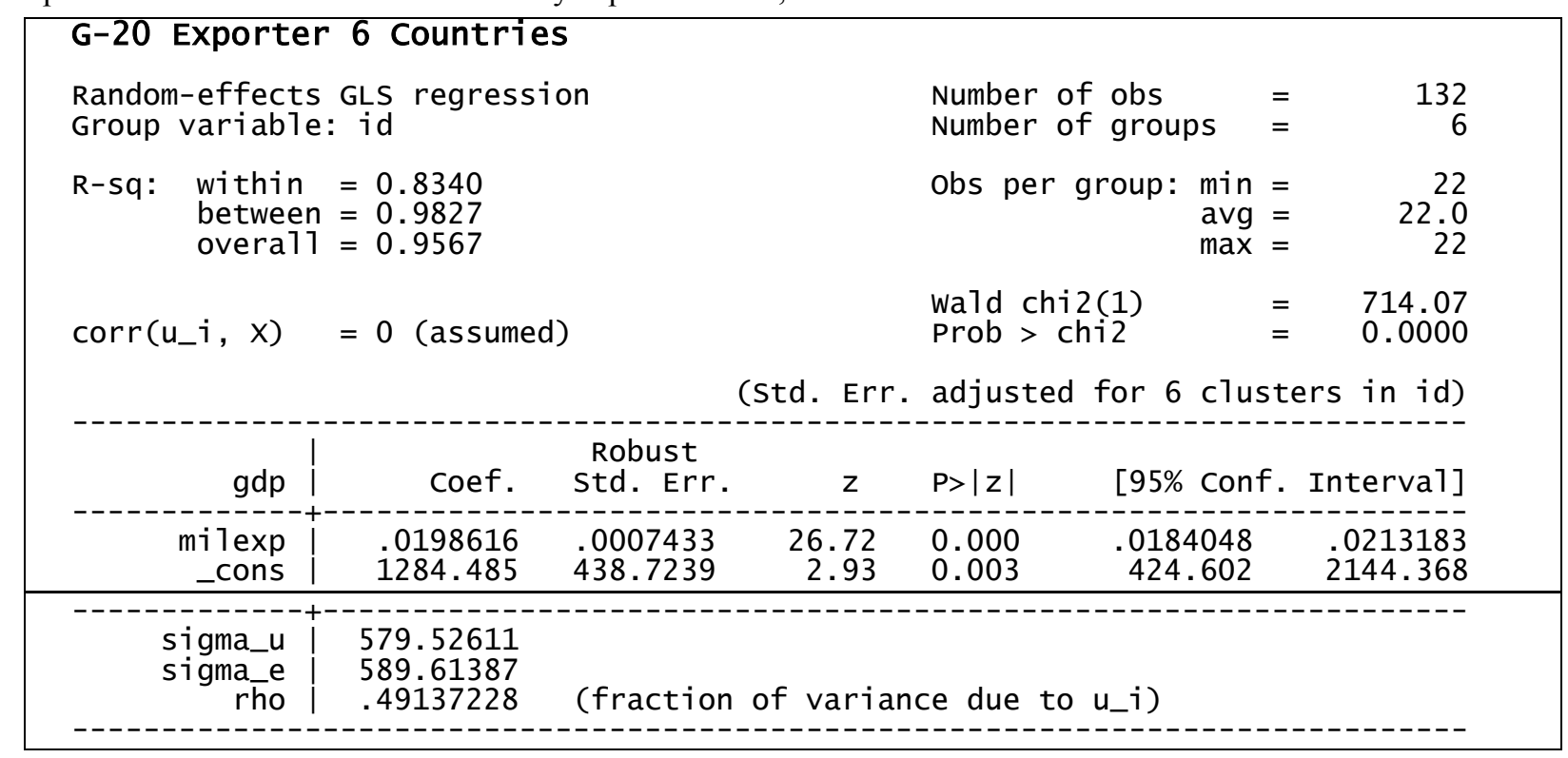

Table-3: G-20 Exporter 6 Countries Panel Econometrical Model Output

It is seen that defense expenses have a positive effect on six arms-exporting countries, when the model is examined. It has power to create $1 \%$ increase on military expenses and $0,020 \%$ increase on GSMH. 


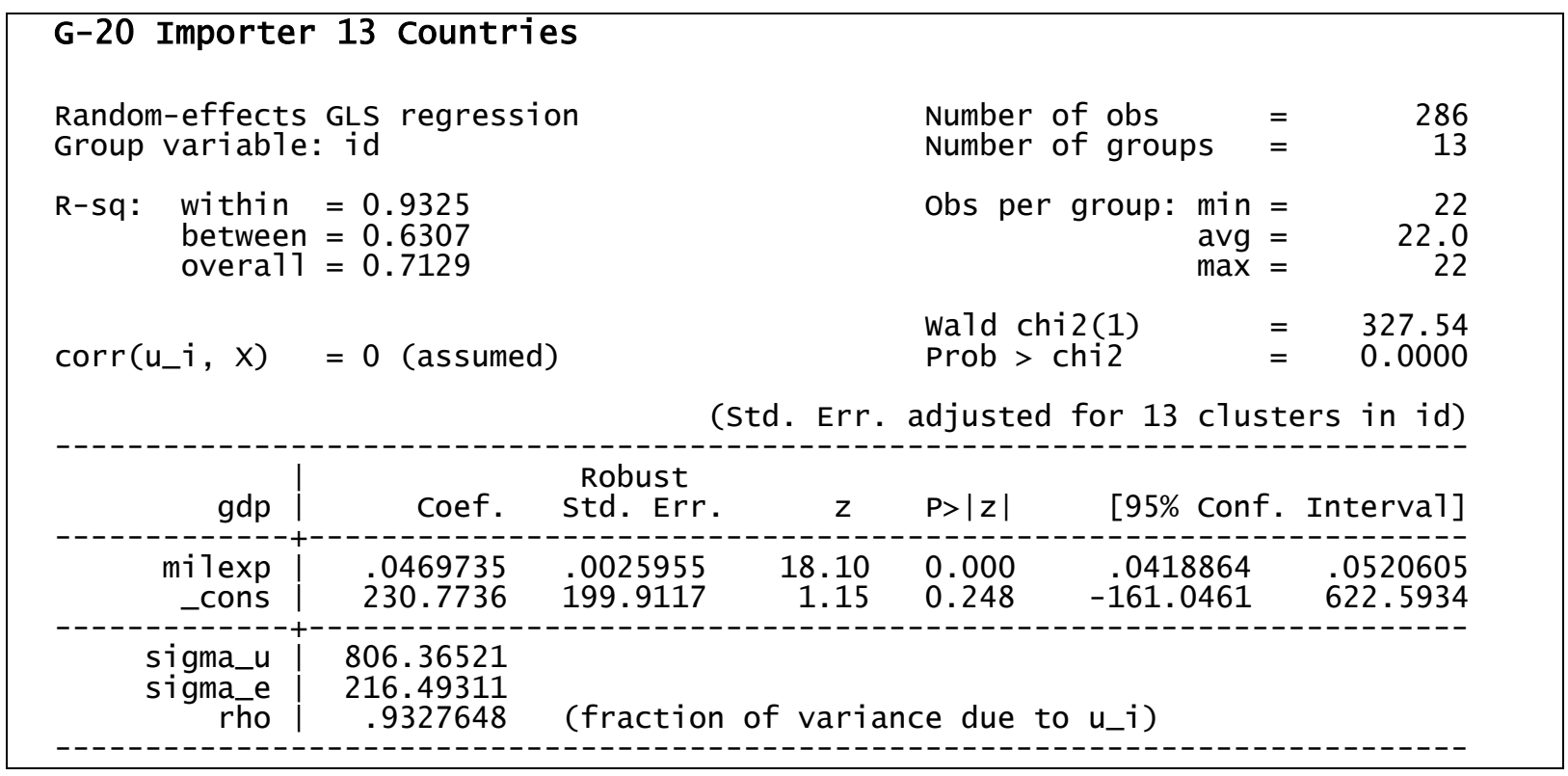

Table-4: G-20 Importer 13 Countries Panel Econometrical Model Output

7It is seen that defense expenses have a positive effect on thirteen arms-exporting countries, when the model is examined. It has power to create $1 \%$ increase on military expenses and $0,046 \%$ increase on GSMH. It is interesting that it has a bigger elasticity on these arms-importing countries.

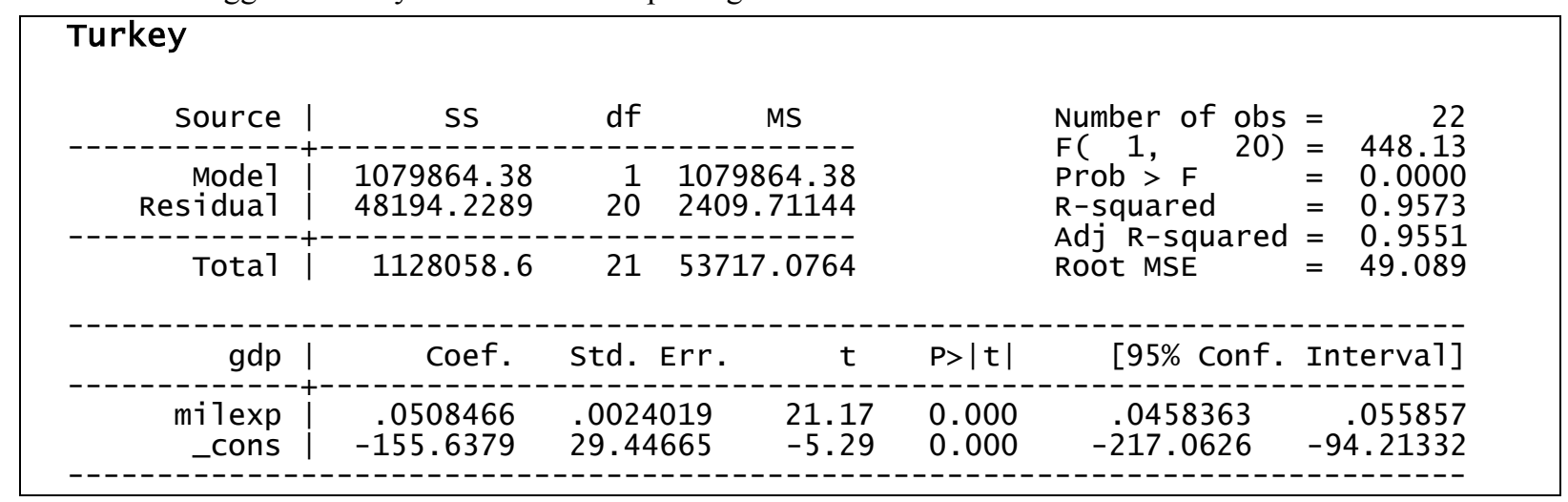

Table-5: Turkey Econometrical Model Output

It is seen that defense expenses have a positive effect on Turkey, when the model is examined. It has power to create $1 \%$ increase on military expenses and $0,050 \%$ increase on GSMH. It can be said that elasticity of defense expenses of national income in Turkey is very high among G-20.

\section{Conclusion:}

It is seen that defense expenses have a positive effect on general of G-20, when the first model is examined. It has power to create $1 \%$ increase on military expenses and $0,022 \%$ increase on GSMH.

It is seen that defense expenses have a positive effect on six arms-exporting countries, when the second model is examined. It has power to create $1 \%$ increase on military expenses and $0,020 \%$ increase on GSMH.

It is seen that defense expenses have a positive effect on thirteen arms-exporting countries, when the third model is examined. It has power to create $1 \%$ increase on military expenses and $0,046 \%$ increase on GSMH. It is interesting that it has a bigger elasticity on these arms-importing countries.

It is seen that defense expenses have a positive effect on Turkey, when the model belong to Turkey is examined. It has power to create $1 \%$ increase on military expenses and $0,050 \%$ increase on GSMH. It can be said that elasticity of defense expenses of national income in Turkey is very high among G-20.

\section{Discussion:}

It is reached the end of that defense expenses of these already developed countries have a positive effect on growth when G-20 countries were examined in terms of defense expenses. This positive effect results from 
technology generation effect of defense expenses in already industrialized countries. It is necessary to discuss that elasticity of defense expenses of national income in thirteen arms-exporting countries and Turkey are very high among G-20. It is obviously seen that income generation effect of improving defense industry in Turkey and increasing defense expenses can be obviously seen at the end of these models.

\section{References}

- Baltagi B.H., (1995), Econometric Analysis Of Panel Data, John Wiley \& Sons Ltd, England

- Benoit, E. (1973) Defense and economic growth in developing countries. Boston: D.C. Heath \& Company.

- Greene, W.H. (2003), Econometric Analysis, Prentice Hall, New Jersey

- Griffits, W. E. R \& Carte H. (1993). Learning And Practicing Econometrics, John Wiley, New York,

- Günlük-Şenesen G. , "The Role Of Defence On External Indebtedness: An Assessment Of Turkey", Defence And Peace Economics, Vol.15, No.2, Pp.145-156, 2004

- Günlük-Şenesen G. , "Türkiye’de Savunma Harcamaları Ve Ekonomik Etkileri, 1980-2001, Kitap", Tesev, İstanbul, 2002

- Harp Ekonomisi; Harp Akademisi Komutanlığı Yayınları; İstanbul; 1985

- Hsiao C. (1986) Analysis Of Panel Data, Cambridge University Press

- $\quad$ IMF Database (C) IMF 2014

- Kennedy, Paul M.; Rise and Fall of the Great Powers: Economic Change and Military Conflict from 1500 to 2000

- Kollias, C., \& Paleologou, S.M, (2013). Guns, Highways and Economic Growth in the United States. Econ. Model. 30: 449-455..

- $\quad$ Kollias, C., Naxakis, C., \& Zaranga, L., (2004). Defence Spending and Growth İn Cyprus: A Causal Analysis. Defence And Peace Economics 15: 299-207

- Pazarlıoğlu, .M. V. (2001) 1980-1990 Döneminde Türkiye’de İç Göç Üzerine Ekonometrik Model Çalışması, V.Ulusal Ekonometri Ve İstatistik Sempozyumu, 19-22 Eylül 2001, Adana

- Pazarlığlu, Gürler; Telekomünikasyon Yatırımları Ve Ekonomik Büyüme: Panel Veri Yaklaşımı; 8. Türkiye Ekonometri Ve İstatistik Kongresi 24-25 Mayıs 2007 - İnönü Üniversitesi Malatya

- $\quad$ SIPRI Military Expenditure Database C SIPRI 2014

- $\quad$ Sümer K.K., "Savunma Harcamalarının Ekonomik Büyüme Üzerine Etkisinin İncelenmesi", Harp Akademileri Komutanlığı Güvenlik Stratejileri Dergisi, Ss.80-91, 2005

- Tatoğlu, Ferda (2012) Yerdelen Panel Veri Ekonometrisi; Beta Basım A.Ş.; Istanbul; 2012

- Yildirim, J., Sezgin, S. \& Ocal, N., (2005), Military Expenditure and Economic Growth İn Middle Eastern Countries: A Dynamic Panel Data Analysis. Defence And Peace Economics 16(4): 283-295

\section{Annex}

\begin{tabular}{|c|c|}
\hline & $\begin{array}{cc}\text { (b) } & \text { (B) } \\
\text { fe } & \text { re }\end{array}$ \\
\hline milexp | & $.0221463 \quad .0224114$ \\
\hline $\begin{array}{r}\mathrm{B}= \\
\text { Test: } \mathrm{Ho}:\end{array}$ & $\begin{array}{l}\mathrm{b}=\text { consistent under Ho and Ha; obtained from xtreg } \\
\text { inconsistent under Ha, efficient under Ho; obtained from xtreg } \\
\text { difference in coefficients not systematic } \\
\qquad \begin{aligned} \text { chi2 }(1)= & (b-B)^{\prime}\left[\left(V_{-} b-V_{-} B\right) \wedge(-1)\right](b-B) \\
= & 2.11\end{aligned} \\
\begin{aligned} \text { Prob }>\text { chi2 }= & 0.1464\end{aligned}\end{array}$ \\
\hline
\end{tabular}

Annex 1: Hausman Test Result 


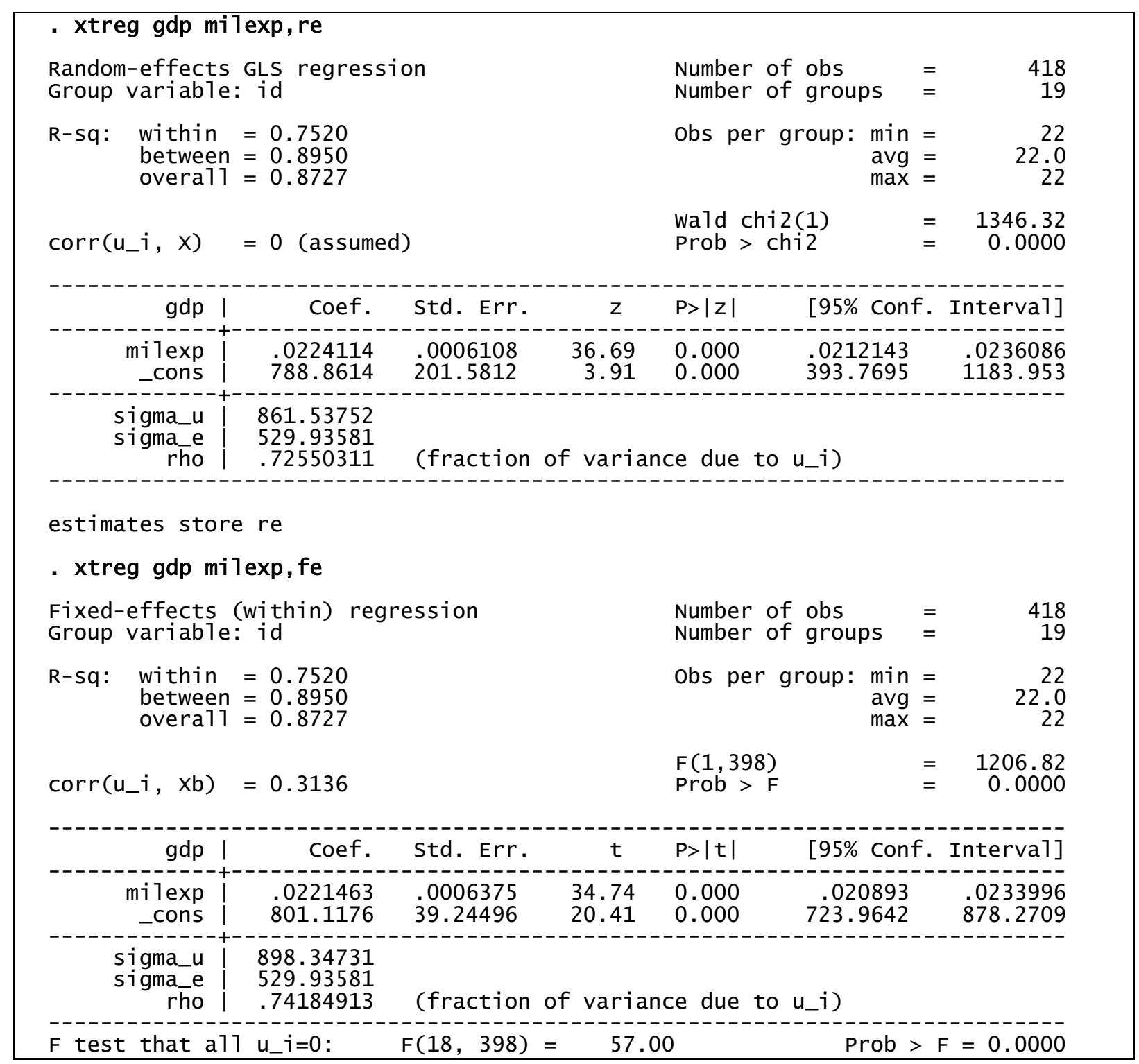

Annex 2: Pooled Model and Fixed Effects Model Results 